\title{
SENSATION SEEKING AND STRESS COPING STRATEGIES OF PARTICIPANTS IN MILITARY MISSIONS IN AFGHANISTAN AND ANTARCTIC EXPEDITIONS
}

\author{
Tatiana Iancheva, Galina Domuschieva - Rogleva, Milena Kuleva \\ National Sports Academy "Vassil Levski"
}

\begin{abstract}
The activities performed by people who go on military missions or on Antarctic expeditions to Livingston Island often arise various questions and interpretations. On the one hand, they suppose a tendency toward risky acts; on the other hand, they require discipline and balance in one's behavior.

The aim of our study was to examine the peculiarities of the need of security and the need of sensation seeking as basic personal variables of participants in military missions in Afghanistan and Bulgarian Antarctic expeditions and to examine their relation to the coping strategies applied.

The research was done among 141 individuals (107 participants in Bulgarian military contingent which took part in an international NATO mission in Afghanistan in 2017 and 34 participants in two Bulgarian Antarctic expedition on Livingston Island in 2014/2015 and 2016/2017. All the individuals researched were divided into groups according to their age, gender and rank.

We used: 1) Need of security assessment test (A. Velichkov, M. Radoslavova, S. Vassileva, V. Todorov, 1998). 2) Coping Orientations to Problems Experienced Scale-COPE - 1 (Carver, et al, 1989), adapted for Bulgarian conditions (M. Georgiev et al, 2003) and 3) Research methods of psychic instability and sensation seeking, adapted by A. Velichkov and M. Radoslavova (2005). It is based on M. Zuckerman's methods $(1979,1994)$.

The researched participants in military missions and the explorers from Antarctic expeditions showed significant differences along the indexes between the two groups. The participants in military mission have lower values along all scales of the need of sensation seeking in comparison with the established norms for the Bulgarian sample and higher values of the need of security. The results of the participants in the Antarctic expeditions are particularly interesting. Regardless of their pronounced inclination to adventurous experiences and risky behavior, to hasty and impulsive actions, when subjected to tension, uncertainty and stress they revert to cognitive engaged coping strategies, which suppose active coping, planning, mobilization and a sense of control over the situation.

The established regularities are a valuable reference point both for the selection of the participants in military missions and expeditions and for the insurance of their safety.
\end{abstract}

Key words: need of security, sensation seeking, military missions, stress coping strategies, Antarctic expeditions.

\section{INTRODUCTION}

A lot of people take part in risky, adventurous activities and this arises different questions and interpretations. Why do these people take such a risk? Are there any personal prerequisites determining their choice? If those are people inclined to risky behavior, how are the balance, discipline and regulation of this behavior achieved?

These questions directed our scientific in- terest to research of some personal variables of participants in military missions and Antarctic expeditions which, according to authors, are related on the one hand to an inclination to sensation seeking, and on the other hand, to ways of coping with stress and tension during such missions.

The need of security concerns a person's basic motivation. It is vital for the process of development and functioning of a person, for 
emotional reactions and building a system of cognitive-motivational structures for regulation of people's behavior and actions, especially in situations involving threat, tension and potential risk. Depending on the level of its manifestation there are certain differences in behavior and coping strategies in extreme situations, in the intensity of emotional reactions towards threatening signals, as well as in cognitive assessments of the threat involved.

Some stable individual differences in emotional reactions to threatening stimuli have been established according to the intensity people experience positive and negative emotions depending on their different need of security level (Larsen, Billings, Cutler, 1996).

The fulfillment of the need of security is prerequisite for maintaining a person's emotional stability. The feeling of personal security and ability to have control over the course of the events play a major role in the organization and functioning of a person.

People with low need of security level are viewed as emotionally more stable to threatening stimuli.

Different behavior strategies in situation involving potential risk have been established as well (Velichkov, Radoslavova, 2000). People with high need of security tend to use more various coping strategies, and most often it is seeking support on behalf of other people. Those with low need of security are more oriented to ignoring the threat and seeking their own ways to cope with the situation. There are also differences in the cognitive assessments of the context. People with low need of security process the information more realistically and make more moderate assessments of the probability of threat presence.

The cognitive assessment of a situation or events provokes certain emotions which consequently generate cognitive and behavior activity (Lewis, 1996). If one assesses a situation as insecure, unfamiliar or unusual according to their own experience, it could provoke fear or anxiety. If it is perceived as a new or challenging one, it could lead to pleasure, delight or surprise (Roseman, Antoniou, Jouse, 1996).

According to some authors (Carver, Sutton, Scheier, 2000) the result from the cognitive-emotional assessment usually leads to two general behavior strategies: avoidance and active coping with a situation. However, one logically asks oneself - what kind of behavior strategies do people with very low or insignificant need of security levels revert to?

Sensation seeking, inclination to challenges is a basic personal characteristic of neurobiological nature. M. Zuckerman defines it as "a feature, a determining trend towards seeking various, new, complex and strong sensations and experiences, the readiness to take physical, social, legislative or financial risk because of such experiences" (Zuckerman, 1994).

M. Zuckerman develops a theoretical model in order to explain a wide range of behavior types. The theory of the optimal level of arousal lies at the base of his concept for sensation seeking, according to which every person possesses a preferred or optimal level of stimulation. It predisposes the intensity of the most efficient performance (Jones, 1995; Shoham \& Rose, 1998). These differences affect the choice of a type of activity (Zuckerman, 1979, 2007).

People with high sensation seeking level tend to be more adventurous, impulsive, and quick-tempered which can provoke involvement in risky activities and an easy loss of control. Those ones with low sensation seeking level tend to be more cautious and stability seeking and prefer to avoid the unknown and unexpected things (Vassileva, 2002).

A number of surveys show that people inclined to sensation seeking usually choose more risky professions or sports (Zuckerman, 1979, 1994; Campbell, Tyrell \& Zingaro, 1993; Wagner \& Houlihan, 1994; Iancheva, 2004, Domuschieva-Rogleva \& Iancheva, 2017).

Proneness to risky behavior and its conse- 
quences make researchers look for their relation to different coping strategies.

Coping strategies are defined by many scientists as a complex, dynamic, multidimensional process (Crocker \& Graham, 1995; Crocker \& Isaak, 1997; Eklund, Gould \& Jackson, 1993; Gould, Udry, Bridges \& Beck, 1997). Coping aims at regulating emotions and changing behavior so that we can do better in a particular situation. Coping with a situation requires a change in one's behavior and/ or cognitions in order to manage the situation better. Lazarus and Folkman define it as "a process of constantly changing cognitive and behavior efforts to manage specific inner and/ or outer requirements or conflicts, determined as exceeding one's own resources" (Lazarus \& Folkman, 1984, p.141). Coping is a response to the perception of threats which appear in the environment. Most authors are unanimous that coping consists of conscious psychological and psychic efforts aimed at improvement of our own resourcefulness when dealing with stressful events or at a decrease in the outer pressure (Anshel et al., 2001). Implementation of certain coping strategies supposes awareness that the problem or situation are problematic ones.

Participation in military missions is a specific activity which supposes on the one hand inclination to risk taking and a certain amount of adventure spirit, and on the other hand - it requires strict discipline and observation and adherence to the rules.

The activity of the participants in the Antarctic expeditions on Livingston Island is highly dependent on the extreme living conditions, the frequent climatic changes, strong winds, and snowfall. According to some researchers this is "the worst weather on earth".

There is a considerable interest towards psychological changes and functioning of the members of polar expeditions (Gunderson, 1974; Gunderson \& Pálinkás, 1991; Pálinkás, Suedfeld \& Steel, 1995; Suedfeld, 2001). In some surveys the authors seek the influence of the inner self-concept, interpersonal relationships and personal characteristics on the activities during polar expeditions (Pálinkás \& Johnson, 1990; Pálinkás, 2003; Rosnet, LeScanff \& Sagal, 2000).

The aim of our study was to examine the peculiarities of the need of security and the need of sensation seeking as basic personal variables of participants in military missions in Afghanistan and Bulgarian Antarctic expeditions and to examine their relation to the coping strategies applied.

\section{METHODOLOGY}

The research was done among 141 individuals (107 participants in Bulgarian military contingent which took part in an international NATO mission in Afghanistan in 2017 and 34 participants in two Bulgarian Antarctic expedition on Livingston Island in 2014/2015 and 2016/2017, aged between 23 and 70 years. There were 128 men and 13 women. The average age of the researched individuals is 42.5 years. For the purposes of the study the members of the armed forces were divided into age groups (23 - 30 years; 31 - 40 years; $41-56$ years), gender, work experience (less than 10 years, from 11 to 20 years and over 21 years), and rank (soldiers, sergeants and officers).

The research among the military men was done right after their return from Afghanistan at Military Medical Academy in Sofia, at Psychic Health and Prevention Centre, and the research among the participants in the Antarctic expeditions - during the last days of their stay on Livingston Island.

\section{Methods}

In order to fulfil the aim of the research we used:

Need of security assessment test (A. Velichkov, M. Radoslavova, S. Vassileva, V. Todorov, 1998).

Research methods of psychic instability and sensation seeking, adapted by A. Velich- 
kov and M. Radoslavova (2005). It is based on M. Zuckerman's methods $(1979,1994)$ and comprises three scales:

Sensation seeking;

Functional impulsivity;

Dysfunctional impulsivity

The scale includes 79 items.

Coping Orientations to Problems Experienced scale - COPE - 1, Carver, et al., 1989). The scale includes 52 items, organized in 14 subscales. After an additional factor analysis, they were reduced to three generalized secondary factors: cognitive engagement, emotional engagement, cognitive and emotional disengagement (M. Georgiev, et all, 2003).

\section{Statistical Analysis}

In order to process the initial data from the research we used the statistical program SPSS
21 , and did an alternative analysis (to establish the relative shares of different responses in the questionnaires, as well as to process the personal information such as gender, age, work experience, rank), correlation analysis, comparative analysis (ANOVA, U-criterion of Mann-Whitney and Criterion of KruskalWallis), and regression analysis.

\section{RESULTS AND ANALYSIS}

The results obtained from the variation analysis are presented in table 1.

The data, to some extent, differs from our preliminary expectations. A number of surveys show (Zuckerman, 1979, 1994) that the people who are inclined to sensation seeking usually choose more risky professions.

Table 1. Results from the variation analysis of the data

\begin{tabular}{lccccccccc} 
& $\mathrm{N}$ & Min & Max & M & Std. Dev. & As & Std. Error & Ex & Std. Error \\
\cline { 2 - 9 } Age & 141 & 23,00 & 70,00 & 42,01 & 12,59 &, 717 &, 204 &,- 518 &, 406 \\
Cognitive engagement & 141 & 1,15 & 3,85 & 2,75 &, 55 & $-2,148$ &, 217 & 8,801 &, 431 \\
Emotional engagement & 141 & 1,17 & 3,75 & 2,32 &, 52 & $-1,350$ &, 217 & 5,077 &, 431 \\
Cogn-emot disengagement & 141 & 1,00 & 3,13 & 1,66 &, 43 &,- 311 &, 217 & 3,297 &, 431 \\
Need of security & 141 & 4,00 & 18,00 & 11,73 & 3,27 &,- 988 &, 217 & 1,744 &, 431 \\
Sensation seeking & 141 &, 00 & 1,17 &, 41 &, 20 &, 339 &, 204 &, 556 &, 406 \\
Functional impulsivity & 141 &, 10 &, 90 &, 53 &, 22 &,- 847 &, 204 &,- 098 &, 406 \\
Dysfunctional impulsivity & 141 &, 00 &, 80 &, 21 &, 20 & 1,382 &, 204 & 1,269 &, 406 \\
\hline
\end{tabular}

The results from our research reveal that there are lower values both among the military men and among the participants in the Antarctic expeditions from our sample along all scales of the need of sensation seeking than the mean values of the Bulgarian sample (figure 1) and similar values in the need of security (Velichkov \& Radoslavova, 2005).
Our previous surveys (Iancheva, 2004), done among mountaineers and climbers, as representatives of sports directed to challenge, new impressions and experiences, risky and adventurous performances, reveal significantly higher values along all scales of the need of sensation seeking. 


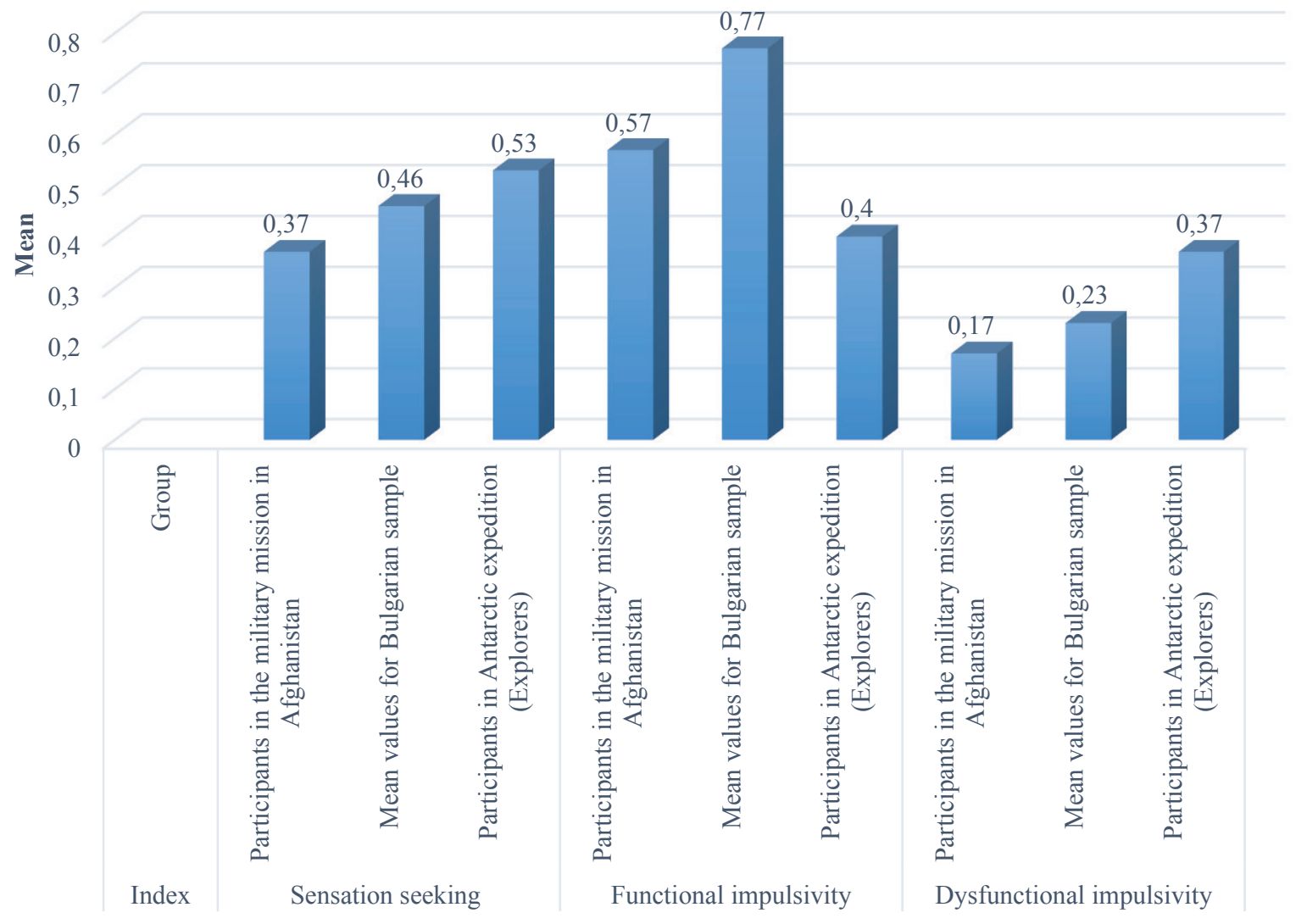

Figure 1. Mean values of the researched indexes among missionaries, Bulgarian sample and participants in Antarctic expedition

The data from the research show that the "functional impulsivity" scale has significantly higher values than the scale "dysfunctional impulsivity" (table 1). These results are favorable because functional impulsivity is related to risk taking tendency, quick and adequate reaction in extreme situations, feeling of enthusiasm, bravery and activeness. Dysfunctional impulsivity supposes higher impulsivity and lack of any restraints, tendency to ignore facts, hastiness and very often defiance of the rules.

The analysis of the results, related to the coping strategies (table 1), reveals that the leading strategy is the cognitive engagement one, which includes active coping, planning, suppressing competitive activities, positive redefinition, development and restraint
$(\mathrm{M}=2.75 ; \mathrm{SD}=.55)$. It is followed by the strategy emotional engagement $(\mathrm{M}=2.32 ; \mathrm{SD}=.52)$ - seeking advice and help, need of emotional response, compassion and mutual experience (table 1). The lest preferred is the strategy cognitive and emotional disengagement $(\mathrm{M}=1.66$; $\mathrm{SD}=.43$ ), which includes denial or lack of acceptance, behavior or psychic disengagement, use of alcohol or drugs, reconciliation with what has happened, turning to religion. As a whole, our results confirm the results obtained by other authors.

The results from the comparative analysis (table 2) reveal significant differences along four of the researched parameters - sensation seeking, functional impulsivity, dysfunctional impulsivity and need of security. 
Table 2. Results from the comparative analysis of the results among the groups

\begin{tabular}{|c|c|c|c|c|c|}
\hline & & $\mathbf{N}$ & Mean & $\mathbf{U}$ & Sig. \\
\hline \multirow{3}{*}{ Cognitive engagement } & Military & 107 & 2,76 & & \\
\hline & Explorers & 34 & 2,98 & 764,5 & 292 \\
\hline & Total & 141 & & & \\
\hline \multirow[t]{3}{*}{ Emotional engagement } & Military & 107 & 2,34 & & \\
\hline & Explorers & 34 & 2,54 & 809,0 & ,465 \\
\hline & Total & 141 & & & \\
\hline \multirow{3}{*}{$\begin{array}{l}\text { Emotional and cognitive dis- } \\
\text { engagement }\end{array}$} & Military & 107 & 1,66 & & \\
\hline & Explorers & 34 & 1,83 & 804,5 & ,445 \\
\hline & Total & 141 & & & \\
\hline \multirow[t]{3}{*}{ Need of security } & Military & 107 & 12,42 & & \\
\hline & Explorers & 34 & 8,33 & 225,5 &, 000 \\
\hline & Total & 141 & & & \\
\hline \multirow[t]{3}{*}{ Sensation seeking } & Military & 107 & ,37 & & \\
\hline & Explorers & 34 &, 53 & 941,0 &, 000 \\
\hline & Total & 141 & & & \\
\hline \multirow[t]{3}{*}{ Functional impulsivity } & Military & 107 & ,57 & & \\
\hline & Explorers & 34 & 40 & 1126,0 &, 001 \\
\hline & Total & 141 & & & \\
\hline \multirow[t]{3}{*}{ Dysfunctional impulsivity } & Military & 107 & ,17 & & \\
\hline & Explorers & 34 & 37 & 911,0 & 000 \\
\hline & Total & 141 & & & 然, \\
\hline
\end{tabular}

There are higher values along the indexes sensation seeking and dysfunctional impulsivity among the participants in the Antarctic expeditions and lower values of functional impulsivity and need of security. They are more inclined to impulsive behavior, hasty actions and unconsidered risk, but at the same time they are more emotionally stable to threatening stimuli, oriented mainly towards ignoring the threat and seeking their own ways of coping with the situation. They process the information more realistically and make more moderate assessments of the probability of emergence of some kind of threat.

There are higher values of functional impulsivity and need of security among the military men. According to some data found in literature, people with different need of security levels turn to different behavior strategies in potentially risky situations (Velichkov, Radoslavova, 2000). People with high need of security tend to use more various coping strategies. Most often this is seeking another peo- ple's support. There are some differences in the cognitive assessments of the context. We did not find any statistically significant differences between the two groups as regards stress coping strategies.

The comparative analysis in the group of the military men according to their rank reveals significant differences along four of the researched indexes - need of security $(\mathrm{F}=3,7$; $\mathrm{p}=.028)$, dysfunctional impulsivity $(\mathrm{F}=3,29$; $\mathrm{p}=.041)$, cognitive engaged strategies $(\mathrm{F}=6,27$; $\mathrm{p}=.003$ ) and emotional and cognitive disengagement $(\mathrm{F}=3,2 ; \mathrm{p}=.045)$.

In the group of the officers the leading combination is: sensation seeking, functional impulsivity, cognitive engaged coping strategies. The inclination to risk taking as well as quick, adequate and considered reactions in extreme situations are determined to be leading dispositions.

In the group of the soldiers there is another configuration of the researched parameters: sensation seeking, dysfunctional impulsivity, 
Table 3. Results from the comparative analysis of the data according to the rank

\begin{tabular}{|c|c|c|c|c|c|}
\hline & & $\mathbf{N}$ & Mean & $\mathbf{F}$ & Sig. \\
\hline \multirow[t]{4}{*}{ Cognitive engagement } & Soldiers & 71 & 2,69 & \multirow{4}{*}{6.27} & \multirow{4}{*}{,003 } \\
\hline & Sergeants & 15 & 2,72 & & \\
\hline & Officers & 21 & 3,05 & & \\
\hline & Total & 107 & 2,76 & & \\
\hline \multirow[t]{4}{*}{ Emotional engagement } & Soldiers & 71 & 2,35 & \multirow{4}{*}{, 734} & \multirow{4}{*}{,483 } \\
\hline & Sergeants & 15 & 2,22 & & \\
\hline & Officers & 21 & 2,38 & & \\
\hline & Total & 107 & 2,34 & & \\
\hline \multirow{4}{*}{$\begin{array}{l}\text { Emotional and cognitive } \\
\text { disengagement }\end{array}$} & Soldiers & 71 & 1,72 & \multirow{4}{*}{3.20} & \multirow{4}{*}{, 045} \\
\hline & Sergeants & 15 & 1,47 & & \\
\hline & Officers & 21 & 1,60 & & \\
\hline & Total & 107 & 1,66 & & \\
\hline \multirow[t]{4}{*}{ Need of security } & Soldiers & 71 & 12,11 & \multirow{4}{*}{3.7} & \multirow{4}{*}{,028 } \\
\hline & Sergeants & 15 & 12,00 & & \\
\hline & Officers & 21 & 13,76 & & \\
\hline & Total & 107 & 12,42 & & \\
\hline \multirow[t]{4}{*}{ Sensation seeking } & Soldiers & 71 & 37 & \multirow{4}{*}{,215 } & \multirow{4}{*}{,807 } \\
\hline & Sergeants & 15 & ,40 & & \\
\hline & Officers & 21 & 37 & & \\
\hline & Total & 107 &, 37 & & \\
\hline \multirow[t]{4}{*}{ Functional impulsivity } & Soldiers & 71 & ,55 & \multirow{4}{*}{1.59} & \multirow{4}{*}{,207 } \\
\hline & Sergeants & 15 & 61 & & \\
\hline & Officers & 21 & 62 & & \\
\hline & Total & 107 &, 57 & & \\
\hline \multirow[t]{4}{*}{ Dysfunctional impulsivity } & Soldiers & 71 & ,19 & \multirow{4}{*}{3.28} & \multirow{4}{*}{,041 } \\
\hline & Sergeants & 15 & ,12 & & \\
\hline & Officers & 21 & ,11 & & \\
\hline & Total & 107 & , 17 & & \\
\hline
\end{tabular}

emotional and cognitive disengagement. This could provoke impulsive behavior, ill-considered risk, hasty actions and difficulty in observing order, which could affect participants' safety.

Officers most often choose cognitive engaged strategies for coping with stress and have the lowest values of dysfunctional impulsivity, i.e. they tend to deal with a situation actively and to think over and plan their actions. They feel they have control over a situation and do not ignore facts. They do not take hasty actions and, to a great extent, consider the rules.
There is a reverse trend among soldiers they react impulsively and hastily more often and to a greater extend are capable of violating the rules. They use more often emotional and cognitive disengaged stress coping strategies.

There are significant differences in the cognitive and emotional disengagement according to the work experience. The bigger the work experience, the less used this coping strategy becomes $(F=3,855 ; p=.024)$.

The correlation analysis of the data reveals there are some significant relations between the applied coping strategies and sensation seeking. 
Table 4. Results from the correlation analysis of the data

\begin{tabular}{|c|c|c|c|c|c|c|}
\hline & $\begin{array}{c}\text { Cognitive } \\
\text { engage- } \\
\text { ment }\end{array}$ & $\begin{array}{c}\text { Emotional } \\
\text { engage- } \\
\text { ment }\end{array}$ & $\begin{array}{c}\text { Cogn-emot. } \\
\text { disengagement }\end{array}$ & $\begin{array}{c}\text { Sensation } \\
\text { seeking }\end{array}$ & $\begin{array}{l}\text { Functional } \\
\text { impulsivity }\end{array}$ & $\begin{array}{l}\text { Dysfunctional } \\
\text { impulsivity }\end{array}$ \\
\hline $\begin{array}{l}\text { Cognitive } \\
\text { engagement }\end{array}$ & 1,000 & $.495^{* *}$ & ,116 & , 186 &. $\mathbf{3 0 3}^{* *}$ &,- 116 \\
\hline $\begin{array}{l}\text { Emotional } \\
\text { engagement }\end{array}$ & & 1,000 & $.455^{\text {*** }}$ & , 129 & ,108 & ,147 \\
\hline $\begin{array}{l}\text { Cogn-emot. } \\
\text { disengagement }\end{array}$ & & & 1,000 & ,177 & ,134 & $.375^{* *}$ \\
\hline $\begin{array}{l}\text { Sensation } \\
\text { seeking }\end{array}$ & & & & 1,000 & $.377^{* *}$ & $.345^{* *}$ \\
\hline $\begin{array}{l}\text { Functional } \\
\text { impulsivity }\end{array}$ & & & & & 1,000 & ,111 \\
\hline $\begin{array}{l}\text { Dysfunctional } \\
\text { impulsivity }\end{array}$ & & & & & & 1,000 \\
\hline
\end{tabular}

*Significance at 0,05 level, **Significance at 0,01 level

Sensation seeking is closely related to the two kinds of impulsivity. The first connection reflects the combination between sensation seeking and dysfunctional impulsivity $(\mathrm{r}=.345 ; \mathrm{p}=.000)$ and supposes a pronounced sensation seeking, hasty and impulsive actions. The second connection is with the functional impulsivity $(\mathrm{r}=.377 ; \mathrm{p}=.000)$ and describes people who tend to run risks and are able to react quickly in extreme situations. There is a significant correlation between cognitive engaged strategies and functional impulsivity $(\mathrm{r}=0.303 ; \mathrm{p}=.002)$. This is a logical dependence because cognitive engaged strategies are related to active coping, planning and development which lead to mobilization, a sense of control over a situation and an increased self-confidence. There is also a significant correlation between emotional and cognitive disengagement and dysfunctional impulsivity $\left(\mathrm{r}=0.375^{* *} ; \mathrm{p}=.000\right)$.

The results from the correlation analysis of both groups of researched individuals - participants in military missions and Antarctic expeditions reveal different correlation links.

The established dependencies among the army force confirm, as a whole, the data found in literature and our preliminary hypotheses for existence of some correlations (fig. 2) between cognitive engaged coping strategies and functional impulsivity $(\mathrm{r}=0.303 ; \mathrm{p}=.002)$ and between dysfunctional impulsivity and emotional and cognitive disengagement $(\mathrm{r}=0.375$; $\mathrm{p}=.000)$.

Among the participants in the Antarctic expeditions there are significant correlations between the need of security and emotionally engaged strategies $(r=0.705 ; p=.000)$. People with high need of security are more inclined to apply emotionally engaged coping strategies. The high correlation between dysfunctional impulsivity and cognitive engagement is surprising $(r=0.618 ; p=.000)$, i.e. despite their pronounced inclination to adventurous experiences, hasty and impulsive actions, in a state of tension and stress they revert to cognitive engaged coping strategies which suppose active coping, planning, mobilization and a sense of control over the situation.

We were interested in the issue whether and how much the need of security affected the coping strategies and sensation seeking. In order to assess this influence, we used step regression analysis. The results show that the need of security stimulates functional impulsivity $\left(\beta=.315^{* * *}\right)$, emotionally engaged cop- 


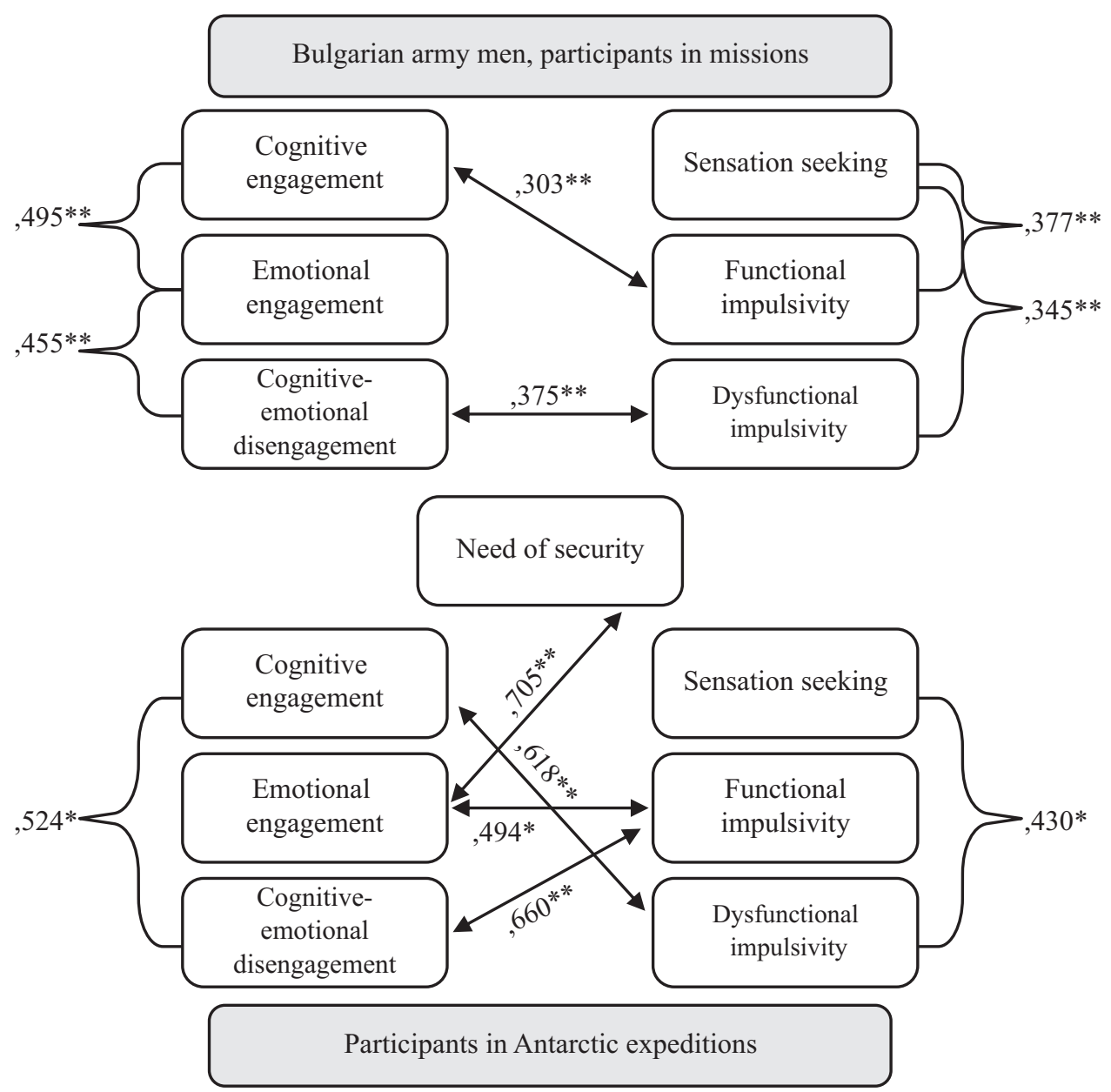

Figure 2. Results from the correlation analysis of the data received from participants in military missions and Antarctic expeditions

ing strategies $(\beta=, 302 * *)$ and is in a reverse dependence on dysfunctional impulsivity $\left(\beta=-, 216^{* *}\right)$, i.e. the high need of security leads to a decrease in dysfunctional impulsivity (table 5).

Table 5. Results from the regression analysis

\begin{tabular}{|c|c|c|c|c|}
\hline \multirow[b]{2}{*}{ Index } & \multicolumn{3}{|c|}{ Need of Security } & \multirow[b]{2}{*}{$\Delta R^{2}$} \\
\hline & $\boldsymbol{\beta}$ & $\mathbf{t}$ & Sig. & \\
\hline Functional impulsivity & 0,315 & 3,672 & 0,000 & 0,092 \\
\hline Emotional engagement & 0,302 & 3,495 & 0,001 & 0,084 \\
\hline Dysfunctional impulsivity & 0,216 & $-2,438$ & 0,016 & 0,039 \\
\hline
\end{tabular}

\section{DISCUSSION}

The results obtained from our research enable a serious analysis and set a number of questions related to behavior management and coping with stress and psychic load of the participants in military missions and Antarctic expeditions in relation to providing their safety.
When researching the participants in Antarctic expeditions, we established lower values of the need of security, higher values of sensation seeking and dysfunctional impulsivity in comparison with the mean values for the Bulgarian sample. We can conclude that they reflect to a great extent the profile of the so called "sensation seekers" who tend 
to choose risky professions and adventurous experiences. There are significant differences along these indexes between the two groups of researched individuals (military men and participants in Antarctic expeditions).

The participants in military mission have lower values along all scales of the need of sensation seeking in comparison with the established norms for the Bulgarian sample and the results of the representatives of the so called "extreme sports", and higher values of the need of security. The results reveal a specific picture of manifestation of the researched parameters among officers and soldiers:

For the officers the leading combination is: sensation seeking, functional impulsivity, cognitive engaged coping strategies. The leading disposition is to take risks and quick, adequate and well-considered reactions in extreme situations.

There is another configuration of the researched parameters among the soldiers: sensation seeking, dysfunctional impulsivity, emotional and cognitive disengagement. This could provoke impulsive behavior, ill-considered risk, hasty actions and difficulty in observing order, which, in turn, would endanger their safety.

There is a specific influence of the work experience on the researched parameters. The bigger the work experience, the less the emotional and cognitive disengagement. We can presume that the specificity of the military activities, the requirements for strict discipline, the observance of the rules and hierarchy create premises for ensuring the balance between the inclination to risk taking and the management of the behavior.

The results of the participants in the Antarctic expeditions are particularly interesting. Regardless of their pronounced inclination to adventurous experiences and risky behavior, to hasty and impulsive actions, when subjected to tension, uncertainty and stress they revert to cognitive engaged coping strategies, which suppose active coping, planning, mobilization and a sense of control over the situation.

The established regularities are a valuable reference point both for the selection of the participants in military missions and expeditions and for the insurance of their safety.

\section{REFERENCES}

Anshel, M.H., Kim, K-W., Kim, B-H., Chang, K-J., \& Eom, H-J. (2001). A model for coping with stressful events in sport: Theory, application, and future directions. International Journal of Sport Psychology, 32(1), 43-75.

Campbell, J., Tyrell, D., and Zingaro, M., (1993). Sensation seeking among white water canoe and kayak paddlers, Personallity and Individual Differences, 14, 489-91.

Carver, C., Sutton, S., Scheier, M., (2000). Action, Emotion, and Personality: Emerging Conceptual Integration. Personality and Social Psychology Bulletin, Vol. 26, Issue 6, 741-752.

Crocker, P.R.E., \& Graham, T.R. (1995). Coping by competitive athletes with performance stress: Gender Differences and relationships with affect. The Sport Psychologist, 9, 325-338.

Crocker, P.R.E., \& Isaak, K. (1997). Coping during competitions and training sessions: Are youth swimmer consistent? International Journal of Sport Psychology, 28, 355-369.

Domuschieva-Rogleva, G.D., Iancheva, T. (2017). Coping strategies for the participants in the Antarctic expedition. In: Revista de Psicología del Deporte., Vol 26, Suppl. 4, pp. 45-50 Journal of Sport Psychology, Vol 26, Suppl. 4, pp. 45-50.

Eklund, R., Gould, D., \& Jackson, S. (1993). Psychological foundations of Olympic wrestling excellence: Reconciling individual differences and nomothetic characterization. Journal of Applied Sport Psychology, 5, 3647.

Georgiev, M., G., Domuschieva-Rogleva, I. Tosheva. (2003). Vtorichni faktori i optimizirane na testa za izsledvane na predpochitanite strategii za spraviane sys stresa - COPE 
- 1. - V: Lichnost, Motivaciia, Sport. Knigi 1- 3. Prosport. S. (in Bulgarian). (Георгиев, М., Г. Домусчиева-Роглева, И. Тошева. (2003). Вторични фактори и оптимизиране на теста за изследване на предпочитаните стратегии за справяне със стреса - COPE-1. B: Личност, Мотивация, Спорт. Книги 1-3 Prosport, C.

Gould, D., Udry, E., Bridges, D., \& Beck, L. (1997). Coping with season - ending injuries. The Sport Psychologist, 11, 379-399.

Iancheva, T., (2004). Lichnost i sastezatelna realizacia, S., NSA PRES. Янчева, T., (2004). Личност и състезателна реализация, C., НСА ПРЕС.

Iancheva, T., M. Kuleva, (2018). Sensation seeking and coping with stress among participants in military missions in Afghanistan, in Proceeding book of Fifth Scientific Conference "Sport and Security", pp. 1419. (In Bulgarian) Янчева, Т., М. Кулева, (2018). Търсене на усещания и справяне със стрес при участници във военни мисии в Афганистан, В Сб.: Доклади от Пета международна научна конференция „Спорт и сигурност“" НСА ПРЕС, С., стр. 14-19

Jones, G., (1995). More than just a game: Research developments and issues in competitive anxiety in sport. British Journal of Psychology, Vol. 86, 4, p. 449-469.

Lazarus, R.S., \& Folkman, S. (1984). Stress, appraisal and coping. Springer.

Lewis, M., (1996). Self-organizing Cognition, and reality: Three memos for the Next Generation of Research. Psychological Inquiry, Vol. 10, Issue 1, 54-59.
Radoslavova, M., A. Velichkov, (2005). Metodi za psihodiagnostika, S., PANDORA PRIM. (In Bulgarian) Радославова, M., А. Величков, (2005). Методи за психодиагностика, С., ПАНДОРА ПРИМ.

Roseman, I., Antoniou, A., Jouse, P., (1996). Appraisal Determinants of Emotions: Constructing a More Accurate and Comprehensive Theory, Cognition and Emotion, 10 (3), 241-277.

Shoham, A., Rose, G., (1998). Marketing of risky sports: From intention to action, Journal of the Academy of Marketing Science, Vol. 26, 17, p. 307-322.

Vasileva, S. (2002). Grupovi i individualni razlichia $\mathrm{v}$ turseneto na useshtania pri sportuvashti I nesportuvashti. Lichnost, motivacia, sport. Sportat i lichnostta. Kn. 1. S. pp 11-19 (In Bulgarian) Василева, С., (2002). Групови и индивидуални различия в търсенето на усещане при спортуващи и неспортуващи, Личност, мотивация, спорт. Спортът и личността, Кн. 1, С. 11-19.

Velichkov, A., M. Radoslavova, (2000). Metod za ocenka na psihologichnata neustoichivost I tursene na useshtania, Balgarsko spisaniepsihologoia.(In Bulgarian)Величков, А., М. Радославова, (2000). Метод за оценка на психологична неустойчивост и търсене на усещания, Българско списание по психология.

Wagner, A., and Houlihan, D., (1994). Sensation-seeking and trait anxiety in handglider pilot and golfers, Personality and Individual Differences, 16, 975-9.

\section{Corresponding author:}

Tatiana Iancheva

Department "Psychology, pedagogy and sociology"

National Sports Academy "Vassil Levski" Studentski grad, 21, Acad. Stefan Mladenov str. Sofia 1700, Bulgaria E-mail: tiancheva@prosport-bg.net 